\title{
Retinal vasculitis in juvenile idiopathic arthritis
}

Ana Carolina Schönrock Carolina Schönrock (UNIPLAC, Lages, SC, Brasil), Luiz Alberto Zago Filho Alberto Zago Filho (UNIPLAC, Lages, SC, Brasil), karoline silva zeni Silva Zeni (UNIPLAC, Lages, SC, Brasil), caio oliveira netto Oliveira Netto (UNIPLAC, Lages, SC, Brasil)

\section{BACKGROUND}

Anterior uveitis is the main ophthalmologic complication in patients with juvenile idiopathic arthritis, however there are other complications such as retinal vasculitis present in approximately $2.5 \%$ of JIA patients. We report a case of retinal vasculitis in a girl with JIA, which despite the institution of early treatment, visual loss was important.

\section{CASE REPORT}

L.H., female, 11 years, $60 \mathrm{~kg}$, diagnosis of JIA from 3 years of age with ocular complication (visual eye loss) by chronic anterior uveitis. It was attended in March 2019 by a picture of arthritis in both knees and decreased visual acuity in the left eye with onset 6 months ago, HSV: 38, PCR: 12, FAN 1/320 nuclear fine dense dotted, negative FR. He was using methotrexate $6 \mathrm{cp} /$ week, folic acid $2 \mathrm{cp} /$ week and presnisone $5 \mathrm{mg} /$ day. In the laboratory of 03/22/2019 the result of the test of Hemosedimentação Speed: 38 , CReactive Protein: 12 and Positive Anti-Nuclear Factor was demonstrated, demonstrating an active state of the disease. After a month, she developed orbital hyperemia, pain and loss of visual acuity in the right eye and retinography evidencing retinal vasculitis (Fig 1). Patient received pulse of methylprednisolone $1 \mathrm{gr} /$ day for three days, prednisone $1 \mathrm{mg} / \mathrm{kg}$ and Adalimumab.

\section{CONCLUSION}

Ophthalmologic evaluation in patients with JIA should be careful and rigorous in order to not only diagnose anterior uveitis, but also other complications such as retinal vasculitis. 